\title{
The effect of feeding different glycerol sources on the performance of lactating sows
}

\author{
${ }^{1}$ Orsolya Vida $-{ }^{1}$ Borisz Egri $-{ }^{2}$ Tamás Tóth \\ ${ }^{1}$ Széchenyi István University, Faculty of Agricultural and Food Sciences, Mosonmagyaróvár, Hungary \\ ${ }^{2}$ Kaposvár University, Faculty of Agricultural and Environmental Sciences, Kaposvár, Hungary \\ orsolya.vida04@gmail.com
}

\begin{abstract}
SUMMARY
Glycerol is a by-product of the biodiesel industry and it might be a good alternative to moderate the energy deficiency of sows during the lactation period. Preliminary experiments were carried out to test the effect of a powder, solid based "food grade" glycerol source with 72.9\% glycerol content (Trial 1) and a liquid "feed grade" glycerol source with $86 \%$ glycerol content (Trial 2) on the performance of lactating sows and their litters. Trial 1 was conducted with 5 Hungarian Large White $\times$ Hungarian Landrace sows/treatment (313 \pm 24.9 kg) and Trial 2 with 12-12 DanAvl (323 $17.0 \mathrm{~kg})$ sows and their litters/treatment. Neither the solid, powder based glycerol (Trial 1), nor the liquid glycerol source (Trial 2) had significant effect on the feed intake, reduction in live weight and back-fat thickness, and weaning-tooestrus interval ( $p>0.05$ ) of lactating sows. In Trial 2, on the $14^{\text {th }}, 21^{\text {st }}$ and $27^{\text {th }}$ days of lactation the milk samples were collected and it was found that $50 \mathrm{~kg} / \mathrm{t}$ glycerol decreased the protein content of milk samples (p<0.05). Glycerol supplementation had no effect on dry matter, fat, lactose content of milk samples ( $p>0.05)$. In Trial 2, no significant difference was found between control and experimental sow groups in triglyceride concentration of blood samples and in the activity of liver enzymes (ALT, AST, GGT; p>0.05), but the concentration of plasma glucose and cholesterol increased tendentiously $(p<0.10)$.

Based on our preliminary results, it can be concluded that additional dose trials are needed to perform in order to study the effect of glycerol supplement on milk production and on metabolic processes of lactating sows.
\end{abstract}

Keywords: sow, lactation, glycerol

\section{INTRODUCTION}

Due to the increasing energy demand, an ascending tendency in the production of biodiesel was presented in the last decade. From the economic point of view, biofuel is the most important product, but about $10 \%$ of glycerol is also produced as a by-product during the processing (Thompson and He 2006).

Glycerol can be found as a temporary compound of biochemical reactions in the body and the action of glycerol depends on the energy demand of the body (Tao et al. 1983). Glycerol has been used as energy supplementation in ruminant and monogastric diets for several decades.

In intensive animal husbandry modern genotype sows can be mated at an earlier age, they give birth and nurse more piglets. Hyperprolific sows are more sensitive to the environmental and nutritional effects, their energy and nutritional requirements are increased, compared to the traditional genotypes. Because of the negative energy balance during lactation, it can happen even at ad libitum feeding, that the body condition of sows is getting worse, and it might have a negative effect on the reproductive and the lifetime performance. Hyperprolific sows are forced to sustain a high milk production from less body fat reserves. Glycerol might be a good alternative to moderate this energy deficiency and provide appropriate energy supply in the feed portion of lactating sow.

Glycerol can be found as a temporary compound of biochemical reactions in the body and its action is determinate by the energy demand of the body. Because of the positive effect on the growth performance, the good quality (,feed grade" with $85 \%$ glycerol content) glycerol can be used mainly in the piglet diets at a rate of 5-10\% (Groesbeck et al. 2008, Lammers et al. 2008, Ziljistra et al. 2009, Shields et al. 2011, Seneviratne et al. 2011) and it can be fed up to $10 \%$ during the fattening period, too (Hansen et al. 2009, Kovács 2010, Madrid et al. 2013, Duttlinger et al. 2015). There are few information in the scientific literature, where glycerol is used in lactating sow diets (Schieck et al. 2010, Hernández et al. 2015). Thus, the aim of our study was to investigate the effect of two different glycerol sources on the performance of lactating sows.

\section{MATERIALS AND METHODS}

\section{Animals and circumstances}

Trial 1 was conducted at a Hungarian Purebred Pig Breeder Farm, in Rábacsécsény. 5 Hungarian Large White $\times$ Hungarian Landrace sows/treatment $(313 \pm 24.9 \mathrm{~kg})$ were used.

The experiment started before farrowing at the day of 106 of gestation and ended at the weaning of piglets on the day of 21 of lactation. Sows were weighed and backfat depth was determined ultrasonically (LeanMeater, Renco Corp., Minneapolis, MN) on day 106 of gestation and at weaning. Sows were fed ad libitum after farrowing and had a free access to water.

Trial 2 was conducted at the Product Development and Monitoring Research Centre of Kaposvár University, in Kaposvár. 12 sows/treatment (DanAvl Genetics, Copenhagen) with an initial BW of $323 \pm$ $17.0 \mathrm{~kg}$ were used. The experiment began one week before farrowing and ended with the weaning of piglets on 27 day of lactation. On day 106 of gestation and at weaning sows were weighed and backfat depth was determined ultrasonically (Lean-Meater, Renco Corp., Minneapolis, MN). 
Dietary treatments

In Trial 1, dietary treatments were formulated on corn-wheat-barley-soybean meal based. The experimental diet was supplemented with solid based glycerol at $10 \mathrm{~kg} / \mathrm{t}$ instead of corn (Table 1).

Feed samples were analyzed for dry matter, crude protein, crude fat, crude fiber and crude ash content according to the Hungarian Standards (MSZ ISO 6496:1993; MSZ 6830-4:1981; MSZ 6830-6:1984; MSZ 6830-7; MSZ ISO 5984).

Before diet formulation glycerol sample was analyzed for glycerol and methanol content with HPLC (Biotronik 2000, Biotronik Wissenschaftliche Geräte $\mathrm{GmbH}$, Germany). Crude glycerol used in this experiment had $72.2 \%$ glycerol content and was methanol free.

Table 1

Composition and analyzed nutrient content of the control and the experimental diet in Trial 1

\begin{tabular}{lcc}
\hline \multicolumn{1}{c}{ Composition } & $\begin{array}{c}\text { Control } \\
\text { diet }\end{array}$ & $\begin{array}{c}\text { Experimental } \\
\text { diet }\end{array}$ \\
\hline Wheat $(\mathrm{kg})$ & 150 & 150 \\
Barley $(\mathrm{kg})$ & 150 & 150 \\
Corn $(\mathrm{kg})$ & 370 & 360 \\
Powder based glycerol $(\mathrm{kg})^{*}$ & - & 10 \\
Cold-pressed sunflower cake $(\mathrm{kg})$ & 50 & 50 \\
Extr. soybean meal $(\mathrm{kg})$ & 160 & 160 \\
Malt sprouts $(\mathrm{kg})$ & 50 & 50 \\
Sunflower oil $(\mathrm{kg})$ & 30 & 30 \\
Vitamin and mineral premix, $4 \%(\mathrm{~kg})$ & $4 *$ & 40 \\
Total $(\mathrm{kg})$ & 1000 & 1000 \\
\hline$\quad$ Nutrient/energy content $(\mathrm{as} \mathrm{in} \mathrm{feed)}$ & & \\
\hline Dry matter $(\mathrm{g} / \mathrm{kg})$ & 906 & 911 \\
Calculated DE $(\mathrm{MJ} / \mathrm{kg})$ & 14.35 & 14.31 \\
Calculated ME $(\mathrm{MJ} / \mathrm{kg})$ & 13.80 & 13.77 \\
Crude protein $(\mathrm{g} / \mathrm{kg})$ & 170 & 165 \\
Crude fat $(\mathrm{g} / \mathrm{kg})$ & 55 & 52 \\
Crude fibre $(\mathrm{g} / \mathrm{kg})$ & 38 & 40 \\
Crude ash $(\mathrm{g} / \mathrm{kg})$ & 52 & 56 \\
Total Lys $(\%)$ & 1.04 & 1.04 \\
Total Met+Cys $(\%)$ & 0.60 & 0.60 \\
Total Thr $(\%)$ & 0.73 & 0.72 \\
Total Trp $(\%)$ & 0.25 & 0.25 \\
\hline No: $\%$ Distrbutor: Adexgo Kf & & \\
\hline
\end{tabular}

Note: *Distributor: Adexgo Kft., Hungary; ${ }^{2}$ producer: Agrofeed Kft. (Győr, Hungary); **Supplied per kilogram of diet: vitamin A, 15 $210 \mathrm{IU}$; vitamin D, $1950 \mathrm{IU}$; vitamin E, $100 \mathrm{mg}$.

In Trial 2, dietary treatments were formulated on barley-wheat-corn-soybean meal based. The experimental diet was supplemented with liquid glycerol at $50 \mathrm{~kg} / \mathrm{t}$ instead of corn (Table 2).

Feed samples were analyzed for dry matter, crude protein, crude fat, crude fiber and crude ash content according to the Hungarian Standards (MSZ ISO 6496:1993; MSZ 6830-4:1981; MSZ 6830-6:1984; MSZ 6830-7; MSZ ISO 5984). Before diet formulation glycerol sample was analyzed for glycerol and methanol content with HPLC (Biotronik 2000, Biotronik Wissenschaftliche Geräte $\mathrm{GmbH}$, Germany). Crude glycerol used in this experiment had $86 \%$ glycerol content and $219 \mathrm{ppm} / \mathrm{kg}$ methanol.
Table 2

Composition and analyzed nutrient content of the control and the experimental diet in Trial 2

\begin{tabular}{|c|c|c|}
\hline Composition & $\begin{array}{c}\text { Control } \\
\text { diet }\end{array}$ & $\begin{array}{c}\text { Experimental } \\
\text { diet }\end{array}$ \\
\hline Wheat (kg) & 326 & 326 \\
\hline Barley (kg) & 180 & 180 \\
\hline Extr. soybean meal $(\mathrm{kg})$ & 126 & 126 \\
\hline Corn $(\mathrm{kg})$ & 100 & 50 \\
\hline Extr. sunflower meal (kg) & 50 & 50 \\
\hline Wheat bran $(\mathrm{kg})$ & 50 & 50 \\
\hline Corn flake meal $(\mathrm{kg})$ & 50 & 50 \\
\hline Dried sugarbeet pulp (kg) & 30 & 30 \\
\hline Fat $(\mathrm{kg})$ & 28 & 28 \\
\hline Rapeseed meal (kg) & 20 & 20 \\
\hline Liquid glycerol, $86 \%(\mathrm{~kg})^{*}$ & - & 50 \\
\hline Vitamin and Mineral premix, $4 \%(\mathrm{~kg})^{* *}$ & 40 & 40 \\
\hline Total (kg) & 1000 & 1000 \\
\hline \multicolumn{3}{|l|}{ Nutrient/energy content (as in feed) } \\
\hline Dry matter (g/kg) & 958 & 926 \\
\hline Calculated $\mathrm{DE}_{\mathrm{s}}(\mathrm{MJ} / \mathrm{kg})$ & 13.96 & 13.95 \\
\hline Calculated $\mathrm{ME}_{\mathrm{s}}(\mathrm{MJ} / \mathrm{kg})$ & 13.34 & 13.31 \\
\hline Crude protein $(\mathrm{g} / \mathrm{kg})$ & 160 & 160 \\
\hline Crude fat (g/kg) & 50 & 49 \\
\hline Crude fibre $(\mathrm{g} / \mathrm{kg})$ & 58 & 58 \\
\hline Crude ash $(\mathrm{g} / \mathrm{kg})$ & 57 & 58 \\
\hline Total Lys (\%) & 0.96 & 0.95 \\
\hline Total Met+Cys (\%) & 0.60 & 0.60 \\
\hline Total Thr (\%) & 0.61 & 0.61 \\
\hline Total Trp $(\%)$ & 0.20 & 0.20 \\
\hline
\end{tabular}

Note: *Distributor: Agros-F Group, Hungary; ${ }^{2}$ producer: BonafarmBábolna Takarmány Kft. (Nagyigmánd, Hungary); **Supplied per kilogram of diet: vitamin A, $12000 \mathrm{IU}$; vitamin D, $2500 \mathrm{IU}$; vitamin E, $175 \mathrm{mg}$; vitamin $\mathrm{K}, 4.1 \mathrm{mg}$; thiamine, $2.7 \mathrm{mg}$; riboflavin, $8 \mathrm{mg}$; niacin, $40 \mathrm{mg}$; pantothenic acid, $18.6 \mathrm{mg}$; pyridoxine, $5.3 \mathrm{mg}$; folic acid, $4.3 \mathrm{mg}$; vitamin B12, $0.04 \mathrm{mg}$; I, 0.7 $\mathrm{mg}$ from ethylenediamine dihydriodide; $\mathrm{Se}, 0.4 \mathrm{mg}$ from sodium selenite; choline, $150 \mathrm{mg}$ from choline chloride; and metal polysaccharide complexes of zinc sulfate (120 mg of $\mathrm{Zn}$ ), iron sulfate ( $90 \mathrm{mg}$ of $\mathrm{Fe}$ ), manganese sulfate (50 mg of $\mathrm{Mn}$ ), and copper sulfate $(20 \mathrm{mg}$ of $\mathrm{Cu})$

\section{Data collection}

In both experiment sows and their backfat thickness were measured when they were moved into farrowing rooms and at weaning. The number of born piglets, the birthweight, the weaning weight and the mortality were also recorded. Before farrowing from the $106^{\text {th }}$ day of gestation sows were fed $3.5 \mathrm{~kg} /$ day. After farrowing feed and water was offered ad libitum. The feed intake was recorded continuously.

In Trial 2, on the $14^{\text {th }}, 21^{\text {st }}$ and $27^{\text {th }}$ days of lactation sows received 10 IU oxytocine (Oxytocine NCP, Kela) via intramuscular injection and milk samples were collected. The dry matter, protein, fat and lactose content of milk samples were analyzed according to the Hungarian Standards (MSZ ISO 6496:2001; MSZ EN ISO 5983-2:2009; MSZ 683019:1979; MSZ 6830-26:1987).

In Trial 2, blood samples were collected from sows on the day of weaning. Plasma glucose, cholesterol, triglyceride, total protein, albumin 
content, and activity of alanine transaminase (ALT), aspartate transaminase (AST), gamma-glutamyl transpeptidase (GGT) liver enzymes were measured (Beckman Coulter, Inc., USA).

\section{Statistical analysis}

Data were analyzed with SPSS 21.0 for Windows program (SPSS Inc., Chicago, USA). KolmogorovSmirnov test, Levene-test, two samples t-test and non- parametric test were used. In all procedures the significance level was $\mathrm{p} \leq 0.05$.

\section{RESULTS AND DISCUSSION}

The two experiments were conducted under different environmental conditions, so the results need to be evaluated separately. Table 3 contains the data of the sow's performance in Trial 1.

The change of the bodyweight, backfat-thickness and feed consumption of the lactating sows in Trial 1 (Solid glycerol source, $10 \mathrm{~kg} / \mathrm{t}$ )

\begin{tabular}{|c|c|c|c|}
\hline & Control diet & Experimental diet & Treatment effect \\
\hline Number of sows & 5 & 5 & - \\
\hline Genotypes & \multicolumn{2}{|c|}{$\mathrm{MNF} \times \mathrm{ML}$} & - \\
\hline Parity & 2.8 & 3.4 & - \\
\hline Days of lactation (day) & 21 & 21 & - \\
\hline Total feed intake (kg/sow) & $105.8 \pm 7.0$ & $94.8 \pm 28.0$ & NS \\
\hline Initial bodyweight (kg) & $318.0 \pm 26.2$ & $307.8 \pm 27.5$ & NS \\
\hline Final bodyweight (kg) & $268.6 \pm 23.7$ & $256.8 \pm 30.0$ & NS \\
\hline Bodyweight loss (kg) & $49.4 \pm 12.8$ & $53.0 \pm 14.6$ & NS \\
\hline Initial backfat (mm) & $21.3 \pm 5.5$ & $21.8 \pm 4.7$ & NS \\
\hline Final backfat (mm) & $17.2 \pm 3.7$ & $18.4 \pm 3.1$ & NS \\
\hline Backfat loss (mm) & $4.1 \pm 2.8$ & $3.4 \pm 2.4$ & NS \\
\hline Weaning-to-oestrus interval (day) & 5 & 5 & - \\
\hline
\end{tabular}

Note: NS=non-significant

In Trial 1, the solid based glycerol source had no statistically proven effect on the lactating sows weight- and backfat loss $(\mathrm{p}>0.05) 10 \mathrm{~kg} / \mathrm{t}$ solid glycerol supplementation had no effect on the weaning-to oestrus interval. Although the feed intake of the experimental group were less $(76.3 \pm 32.19 \mathrm{~kg})$ than the feed intake of the control group, this difference was not significant $(p>0.05)$. Because of the few number of animals ( $n=5 /$ treatment) the results cannot be clearly related to the glycerol content of the experimental feed.

Because of the few numbers of animals there were big differences in the initial parameters of the piglet's performances (total born piglets, birth weight etc.). Therefore the piglet's performances (the number of weaned piglets, mortality, weaning weights) were not evaluated.

In Trial 2 (Table 4), the $50 \mathrm{~kg} / \mathrm{t}$ liquid glycerol supplementation did not influence the lactating sows weight- and backfat loss, weaning-to-oestrus interval and feed intake $(\mathrm{p}>0.05)$. However, Schieck at al. (2010) observed that $60 \mathrm{~kg} / \mathrm{t}$ glycerol supplementation decreased the feed intake compared to the results of the $30 \mathrm{~kg} / \mathrm{t}$ glycerol supplemented group $(6.21 \mathrm{~kg} / \mathrm{day}$ vs. $5.69 \mathrm{~kg} / \mathrm{day} ; \mathrm{p}<0.05$ ).

In Trial 2, within the first $48 \mathrm{~h}$ after farrowing litters were cross fostered, the litter size was adjusted to 12 piglet/sow, therefore in the initial bodyweight of piglets there were no difference between the groups. The piglets of the experimental group were with 0.24 $\mathrm{kg}$ heavier compared to the control group but this difference were not significant $(\mathrm{p}>0.05)$ (Table 5).
Table 4

The change of the bodyweight, backfat-thickness and feed consumption of the lactating sows in Trial 2 (Liquid glycerol source, $50 \mathrm{~kg} / \mathrm{t}$ )

\begin{tabular}{|c|c|c|c|}
\hline & $\begin{array}{c}\text { Control } \\
\text { diet }\end{array}$ & $\begin{array}{c}\text { Experimental } \\
\text { diet } \\
\end{array}$ & $\begin{array}{c}\text { Treatment } \\
\text { effect }\end{array}$ \\
\hline Number of sows & 12 & 12 & - \\
\hline Genotypes & \multicolumn{2}{|c|}{ DanAvl } & - \\
\hline Parity & 2.7 & 2.6 & - \\
\hline Days of lactation (day) & 28.5 & 28.3 & - \\
\hline Total feed intake (kg/sow) & $164.9 \pm 15.2$ & $161.6 \pm 14.1$ & NS \\
\hline Initial bodyweight $(\mathrm{kg})$ & $319.6 \pm 16.5$ & $326.0 \pm 17.7$ & NS \\
\hline Final bodyweight (kg) & $252.5 \pm 25.9$ & $252.5 \pm 20.8$ & NS \\
\hline Bodyweight loss (kg) & $67.2 \pm 25.7$ & $73.5 \pm 17.8$ & NS \\
\hline Initial backfat (mm) & $18.3 \pm 2.9$ & $17.6 \pm 4.0$ & NS \\
\hline Final backfat (mm) & $13.3 \pm 2.6$ & $13.4 \pm 3.3$ & NS \\
\hline Backfat loss (mm) & $5.0 \pm 2.1$ & $4.3 \pm 2.1$ & NS \\
\hline $\begin{array}{l}\text { Weaning-to-oestrus interval } \\
\text { (day) }\end{array}$ & 5 & 5 & - \\
\hline
\end{tabular}

Note: $\mathrm{NS}=$ non-significant

Table 5

The initial and the weaning weight of the piglets in Trial 2

\begin{tabular}{|c|c|c|c|}
\hline & Control diet & $\begin{array}{c}\text { Experimental } \\
\text { diet }\end{array}$ & $\begin{array}{c}\text { Treatment } \\
\text { effect }\end{array}$ \\
\hline Initial bodyweight $(\mathrm{kg})$ & $1.51 \pm 0.29$ & $1.56 \pm 0.28$ & NS \\
\hline Final bodyweight $(\mathrm{kg})$ & $8.03 \pm 2.20$ & $8.27 \pm 1.40$ & NS \\
\hline
\end{tabular}

Note: $\mathrm{NS}=$ non-significant 
In Trial 2 , on the $14^{\text {th }}, 21^{\text {st }}$ and $27^{\text {th }}$ days of lactation milk samples were collected. Table 6 shows the composition of sow milk during lactation.

Table 6

The composition of sow milk during lactation in Trial 2

\begin{tabular}{lccc}
\hline \multicolumn{1}{c}{$(\mathrm{g} / 100 \mathrm{~g})$} & Control diet & $\begin{array}{c}\text { Experimental } \\
\text { diet }\end{array}$ & $\begin{array}{c}\text { Treatment } \\
\text { effect }\end{array}$ \\
\hline Dry matter & $18.74 \pm 1.13$ & $18.49 \pm 1.09$ & NS \\
Crude fat & $7.05 \pm 1.01$ & $7.10 \pm 1.14$ & NS \\
Crude protein & $5.33 \pm 0.40^{\mathrm{a}}$ & $5.15 \pm 0.33^{\mathrm{b}}$ & $\mathrm{p}<0.05$ \\
Lactose & $4.94 \pm 0.60$ & $4.95 \pm 0.76$ & $\mathrm{NS}$ \\
\hline
\end{tabular}

Note: $\mathrm{NS}=$ non-significant; ${ }^{\text {ab }} \min . \mathrm{P}<0.05$

In contrast to Schieck et al. (2010) $50 \mathrm{~kg} / \mathrm{t}$ glycerol supplementation reduced the crude protein content of milk significantly $(\mathrm{p}<0.05)$. Schieck et al. (2010) concluded that the crude protein content of the milk was not affected $(\mathrm{p}=0.16)$ by the dietary treatment, but dry matter $(p=0.07)$, crude fat content $(p=0.09)$ of milk samples tended to increase linearly with increasing dietary glycerol. Crude glycerol had no effect on lactose content of the milk of sows. The results of the milk samples and the good body condition led us to hypothesize, that the sows in our experiment were in energy balance. In contrast to our results, Schieck et al. (2010) reported that milk lactose content increased linearly $(\mathrm{P}=0.09)$, as dietary crude glycerol increased. Schieck et al. (2010) evaluated that the increasing lactose content is an indicator that shows metabolize a portion of the excess plasma glycerol in the blood stream to glucose via gluconeogenesis in case of energy deficiency.

In Trial 2 the plasma triglyceride concentration was not affected by dietary treatments $(p>0.05)$, but cholesterol (control: 2.10 $\pm 0.27 \mathrm{mmol} / \mathrm{l}$ vs. experimental: $2.34 \pm 0.33 \mathrm{mmol} / \mathrm{l}, \mathrm{p}<0.10)$ and glucose concentration (control: $4.84 \pm 0.29 \mathrm{mmol} / \mathrm{l}$ vs. experimental: $5.17 \pm 0.55 \mathrm{mmol} / \mathrm{l}, \mathrm{p}<0.10)$ tended to increase (Table 7).

Table 7

Plasma glucose, cholesterol, triglyceride concentration in Trial 2

\begin{tabular}{lccc}
\hline \multicolumn{1}{c}{$(\mathrm{mmol} / \mathrm{l})$} & Control diet & $\begin{array}{c}\text { Experimental } \\
\text { diet }\end{array}$ & $\begin{array}{c}\text { Treatment } \\
\text { effect }\end{array}$ \\
\hline Glucose & $4.84 \pm 0.29$ & $5.17 \pm 0.55$ & $\mathrm{p}<0.10$ \\
Cholesterol & $2.10 \pm 0.27$ & $2.34 \pm 0.33$ & $\mathrm{p}<0.10$ \\
Triglyceride & $0.89 \pm 0.51$ & $0.98 \pm 0.57$ & NS \\
\hline
\end{tabular}

However, Schieck et al. (2010) reported that the dietary glycerol supplementation had no statistically proven effect on the plasma glucose content.
Dietary glycerol supplementation had no statistically proven effect on the activity of alanine aminotransferase (ALT), aspartate aminotransferase (AST) and gamma-glutamyltransferase (GGT) (Table 8 ), it had no negative effect on the liver functions.

Table 8

The activity of liver enzymes (ALT, AST, GGT)

\begin{tabular}{lccc}
\hline & Control diet & $\begin{array}{c}\text { Experimental } \\
\text { diet }\end{array}$ & $\begin{array}{c}\text { Treatment } \\
\text { effect }\end{array}$ \\
\hline ALT (U/l) & $43.33 \pm 12.19$ & $45.83 \pm 7.78$ & NS \\
AST (U/l) & $39.50 \pm 9.23$ & $33.25 \pm 9.70$ & NS \\
GGT (U/l) & $36.70 \pm 9.49$ & $36.50+10.87$ & NS \\
\hline
\end{tabular}

Note: ALT=alanine transaminase, AST=aspartate transaminase; GGT=gamma-glutamyl transpeptidase; NS=non-significant

\section{CONCLUSION}

Based on the results of these pilot studies the following conclusions can be drawn. Neither $10 \mathrm{~kg} / \mathrm{t}$ powder based, solid (Trial 1) nor $50 \mathrm{~kg} / \mathrm{t}$ liquid glycerol supplementation (Trial 2) had statistically proven effect on feed intake, reduction in live weight and back-fat thickness, and weaning-to-oestrus interval $(\mathrm{p}>0.05)$ of lactating sows. $50 \mathrm{~kg} / \mathrm{t}$ glycerol supplementation decreased the crude protein content of milk samples $(\mathrm{p}<0.05)$ but had no statistically proven effect on dry matter, crude fat, lactose content of milk samples $(p>0.05)$. This led us to the conclusion that the sows were in good body condition, in energy balance. According to these results it is recommended to replicate both trials with sows suffering in energy deficiency. $50 \mathrm{~kg} / \mathrm{t}$,feed grade" glycerol supplementation did not influence the activity of liver enzymes (ALT, AST, GGT) examined significantly $(\mathrm{p}>0.05)$, had no negative effect on the liver functions. Plasma cholesterol concentration was not effected by dietary crude glycerol supplementation, but plasma glucose and cholesterol concentration tended to increase $(\mathrm{p}<0.10)$.

In summary, it can be concluded, that additional dose trials are needed to perform in order to study the effect of glycerol supplement on milk production and on metabolic pathways of lactating sows.

\section{ACKNOWLEDGEMENT}

The publication is supported by the EFOP-3.6.3VEKOP-16-2017-00008 project. The project is cofinanced by the European Union and the European Social Fund.

\section{REFERENCES}

Bergsma, R.-Mathur, P. K.-Kanis E.-Verstegen, M. W.-Knol, E F.-Van Arendonk, J. A. (2013): Genetic correlations between lactation performance and growing-finishing traits in pigs. $\mathrm{J}$. Anim. Sci. 91: 3601-3611
Duttlinger, A. J.-DeRouchey, J. M.-Tokach, M. D.-Dritz, S. S.Goodband, R. D.- Nelssen, J. L.-Houser, T. A.-Sulabo, R. C. (2015): Effects of increasing crude glycerol and dried distillers grains with solubles on growth performance, carcass characteristics, and carcass fat quality of finishing pigs. J. Anim. Sci. 90: 840-852. 
Hansen, A. V.-Strathe, A. B.-Kebreab, E.-France, J.-Theil, P. K. (2012): Predicting milk yield and composition in lactating sows: A Bayesian approach. J. Anim. Sci. 90. 7: 2285-2298.

Hernández, F.-Orengo J.-Villodre, C.-Martínez, S.-López, M. J.Madrid, J. (2016): Addition of crude glycerin to pig diets: sow and litter performance, and metabolic and feed intake regulating hormones. Animal. 10. 6: 919-926.

Kovács P. (2010): A biodízel gyártás során keletkező glicerin takarmányozási célú felhasználása a hízósertéseknél. Palatia Nyomda és Kiadó Kft. 21.

Groesbeck, C. N.-Mckinney, L. J.-Derouchey, J. M.-Tokach, M D.-Goodband, R. D.-Dritz, S. S.-Nelssen, J. L.-Duttlinger, A. W.-Fahrenholz, A. C.-Behnke, K. C. (2008): Effect of crude glycerol on pellet mill production and nursery pig growth performance. J. Anim. Sci. 86: 2228-2236.

Lammers, P. J.-Kerr, B. J.-Weber, T. E.-Bregendahl, K.-Lonergan, S. M.-Prusa, K. J.-Ahn, D. U.-Stoffregen, W. C.-Dozier, W. A.-Honeyman, M. S. (2008): Growth performance, carcass characteristics, meat quality, and tissue histology of growing pigs fed crude glycerin-supplemented diets. J. Anim. Sci. 86: 2962-2970.

Madrid, J.-Villodre, C.-Valera, L.-Orengo, J.-Martínez, S.-López, M. J.-Megías, M. D.-Hernández, F. (2013): Effect of crude glycerin on feed manufacturing, growth performance, plasma metabolites, and nutrient digestibility of growing-finishing pigs. J. Anim. Sci. 91: 3788-3795.
Schieck, S. J.-Kerr, B. J-Baido, S. K.-Shurson G. C.-Johnston, L. J. (2010): Use of crude glycerol, a biodiesel coproduct, in diets for lactating sows. J. Anim. Sci. 88: 2648-2656.

Seneviratne, R. W.-Beltranena, E.-Goonewardene, L. A.-Zijlstra, R. T. (2011): Effect of crude glycerol combined with solventextracted or expeller-pressed canola meal on growth performance and diet nutrient digestibility of weaned pigs. Anim. Feed Sci. Tech. 170: 105-110.

Shields, M. C.-Heugten, E.-Lin X.-Odle J.-Stark. S. (2011): Evaluation of the nutritional value of glycerol for nursery pigs. J. Anim. Sci. 89: 2145-2153.

Tao, R. C.-Kelley, R. E.-Yosimura, H.-Benjamin, F. (1983): Glycerol: its metabolism and use as an intravenous energy source. J. Parenter. Enteral Nutr. 7: 479-488.

Thompson, J. C.-He, B. B. (2006): Characterization of crude glycerol from biodiesel production from multiple feedstocks, Applied Engineering in Agriculture. 22: 261-265.

Vadmand, C. N.-Krogh, U.-Hansen, C. F.-Theil, P. K. (2015): Impact of sow and litter characteristics on colostrum yield, time for onset of lactation, and milk yield of sows. J. Anim. Sci. 93: 2488-2500.

Zijlstra, R. T.-Menjivar, K.-Lawrence, E.-Beltranena, E. (2009): The effect of feeding crude glycerol on growth performance and nutrient digestibility in weaned pigs. Canadian J. Anim. Sci. 89: $85-88$. 